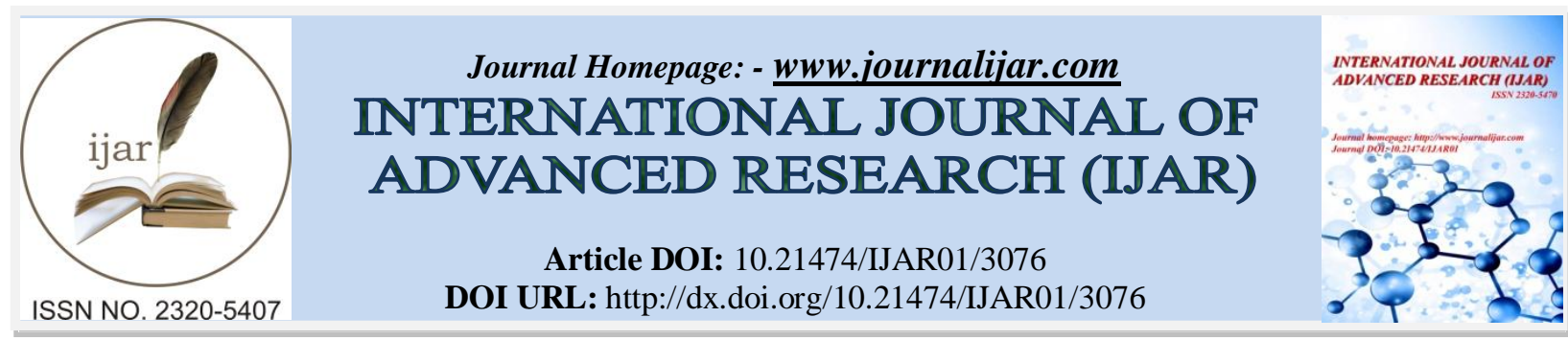

RESEARCH ARTICLE

\title{
HEALTH BELIEFS ABOUT OSTEOPOROSIS AND OSTEOPOROISIS RADIOLOGICAL SCREENING IN OLDER WOMEN AND MEN IN JEDDAH CITY 2016.
}

\author{
Dr. omarhamdi, AL-waleed faydullahal idriss, Heshamzuhairajaj, Shahadahmadbamani and \\ Faisalhammadalatawi.
}

\section{Manuscript Info \\ Manuscript History}

Received: 06 November 2016

Final Accepted: 31 December 2016

Published: January 2017

Key words:-

Osteoporosis, Knowledge, Practice,

Jeddah, Health Beliefs.

\section{Abstract}

Background: Osteoporosis has been recognized as a major public health problem by healthcare providers in Saudi Arabia.

Objective: The present study was designed to examine health beliefs about osteoporosis and osteoporosis radiological screening in a large group of older women and men to determine barriers to screening.

Methodology: This is a self-administrated questionnaire conducted among a sample of 460 man and women in Jeddah, Saudi Arabia.

Results:The majority of the subjects had poor knowledge about osteoporosis and $50.4 \%$ of the subject had no practice to avoid the disease. The level of education showed a significant correlation with knowledge of osteoporosis. Also, the young age, higher level of education and females had significantly higher correlation with good practice.

Conclusion: This study indicated a lack of awareness and practice about osteoporosis. There was a significant association between knowledge and practice with level of education. Also, the female gender and age showed higher practice scores. All these results showed the significance of more health staff involvement regarding to awareness campaign about osteoporosis.

Copy Right, IJAR, 2016,. All rights reserved.

\section{Introduction:-}

Osteoporosis is systemic skeletal disease affecting bone density and its quality leading to bone strength weakening. It is now an established fact that low bone mineral density increases the frequency of bone fractures systemic skeletal disease affecting bone density and its quality leading to bone strength weakening ${ }^{(1)}$.Osteoporosis is a major public health problem in Saudi Arabia and the contributor of mortality and morbidity among elderly people ${ }^{(2,}$ ${ }^{3)}$.According to the International Osteoporosis Foundation (IOF) reports 1,461,401 Saudi persons aged 50 years or more, 8768 would suffer femoral fractures yearly at a cost of $\$ 1.14$ billion ${ }^{(4)}$.After 30 years there is a $1 \%-2 \%$ decline in bone mass each year until menopause, in which $40 \%$ of their total bone mass decrease rapidly due to low estrogen levels ${ }^{(5)}$.Most individuals with osteoporosis are asymptomatic, undiagnosed, and untreated ${ }^{(6)}$.Men appear to be diagnosed and treated less often than women ${ }^{(7)}$.Previous studies suggest that health beliefs are important determinants of whether individuals participate in health screening ${ }^{(8,9)}$. Lack of concern and knowledge can be attributed to lower perceptions of susceptibility ${ }^{(10,11)}$.

The Health Belief Model is a widely used conceptual framework to explain and predict health-related behaviors. This model indicates that patient-level factors related to undertaking health-related action such as disease screening 
include perceived susceptibility to a condition, perceived severity of the condition, perceived benefits to taking a health-related action, perceived barriers to taking action, cues to action (external events that prompt the desire to make a health change), and self-efficacy (belief in one's ability to improve health by taking action ${ }^{(12,13)}$. Despite the magnitude of this preventable health problem, osteoporosis preventive care has not been incorporated into standard primary care practice ${ }^{(14)}$. Forexample, a 2002 survey of 1,500 women ages 40-69 ina managed care health plan showed that only $49 \%$ hadever discussed osteoporosis with a health care provider,and only $12 \%-34 \%$ of high-risk women had bone densitytesting ${ }^{(15)}$.Although evidence-based guidelines support routine osteoporosis screening in women age 65 and older ${ }^{(16)}$. Low levels of risk factor assessment, bone density testing, counseling, and prescription of osteoporosis medications have been documented in primary care practices ${ }^{(6,17,18)}$.

Diagnostic imaging and interventional radiological techniques are increasingly used to diagnose a wide range of diseases, and to give life-saving treatment for many diseases. The use of radiation in medical practices has evolved since its beginning and $30 \%$ to $50 \%$ of medical decisions are based on radiological examinations ${ }^{(17,18)}$.

Our study was designed to examine health beliefs about osteoporosis and osteoporosis radiological screening in a large group of older women and men to determine barriers to screening.

\section{Rationale:-}

Osteoporosis has been recognized as a major public health problem by healthcare providers in Saudi Arabia,according to the International Osteoporosis Foundation (IOF)reports 1,461,401 Saudi persons aged 50 years or older adults demonstrate several beliefs that may be barriers to osteoporosis screening, including low belief in susceptibility to osteoporosis.

These beliefs should be targeted with patient education to improve radiological screening rates.

\section{Objectives:-}

General objectives:-

To examine older adults' beliefs about osteoporosis and osteoporosis radiological screening to identify barriers to screening.

\section{Specific objective:-}

The goal of this study was to examine elderlyhealth beliefs regarding osteoporosis and their perceptions related to radiological screening for the disease, andevaluate the role of demographic factors in shaping elderly beliefs about osteoporosis and assess possible associations between demographic characteristics with the preventive behavior of interest.

\section{Methods:-}

Setting and data collection:

This survey analysis was performed among elderly population in Jeddah city. A pre-formed self-administered questionnaire will be distributed to male and female.

\section{Sample:}

Subjects were chosen according to geographical and sex distribution. Sample size was calculated based on web-site calculator ${ }^{(19)}$,taking the total size of Jeddah population $(3,976,000)^{(20)}$, confidence level $(95 \%)$ and margin error $(5 \%)$ to be 385 , additional $20 \%$ was added to cover the missing data. The total sample obtained was $\mathbf{4 6 0}$.

\section{Study population:}

Both old age male and female in Jeddah citywere included in this study.

\section{Study tool:}

Pre-formed Self-administered questionnaire that requires information about: (osteoporosis and general health-related characteristics, and beliefs about osteoporosis severity, susceptibility, screening self-efficacy, and screening response efficacy).

\section{Study limitations:}

The following limitations are expected: 
- Cooperation of elderly

- Recall bias

Ethical considerations:

An informed consent was maintained from all participants before filling the questionnaire.

Statistical analysis:

Data were fed to the computer and analyzed using IBM SPSS software package version 20.0. Qualitative data were described using number and percent. Significance of the obtained results was judged at the $5 \%$ level.

The used tests were

1 - Chi-square test

For categorical variables, to compare between different groups

\section{2 - Fisher's Exact or Monte Carlo correction}

Correction for chi-square when more than $20 \%$ of the cells have expected count less than 5 .

\section{Results:-}

This study was carried out on 460 elderly both male and female in Jeddah city.

Demographic data:

Table (1), show the demographic data of the studied subjects, the most frequent age group was 61-70 years, the females was slightly higher than male, the education of the majority of the population was university educated (Fig. 1-3).

Table 1:- Distribution of the studied patients regarding demographic data.

\begin{tabular}{|c|c|c|}
\hline & Number & Percent \\
\hline Age & & 19.1 \\
\hline$<40$ & 88 & 18.7 \\
\hline $41-50$ & 86 & 21.1 \\
\hline $51-60$ & 97 & 21.3 \\
\hline $61-70$ & 98 & 19.8 \\
\hline+70 & 91 & 100.0 \\
\hline Total & 460 & 47.0 \\
\hline Gender & & 53.0 \\
\hline Male & 216 & \\
\hline Female & 244 & 1.7 \\
\hline Education & & 12.2 \\
\hline Primary & 8 & 30.4 \\
\hline Middle & 56 & 54.8 \\
\hline Secondary & 140 & .2 \\
\hline University & 252 & .7 \\
\hline Master & 1 & \\
\hline PHD & 3 & \\
\hline & & \\
\hline & & \\
\hline
\end{tabular}




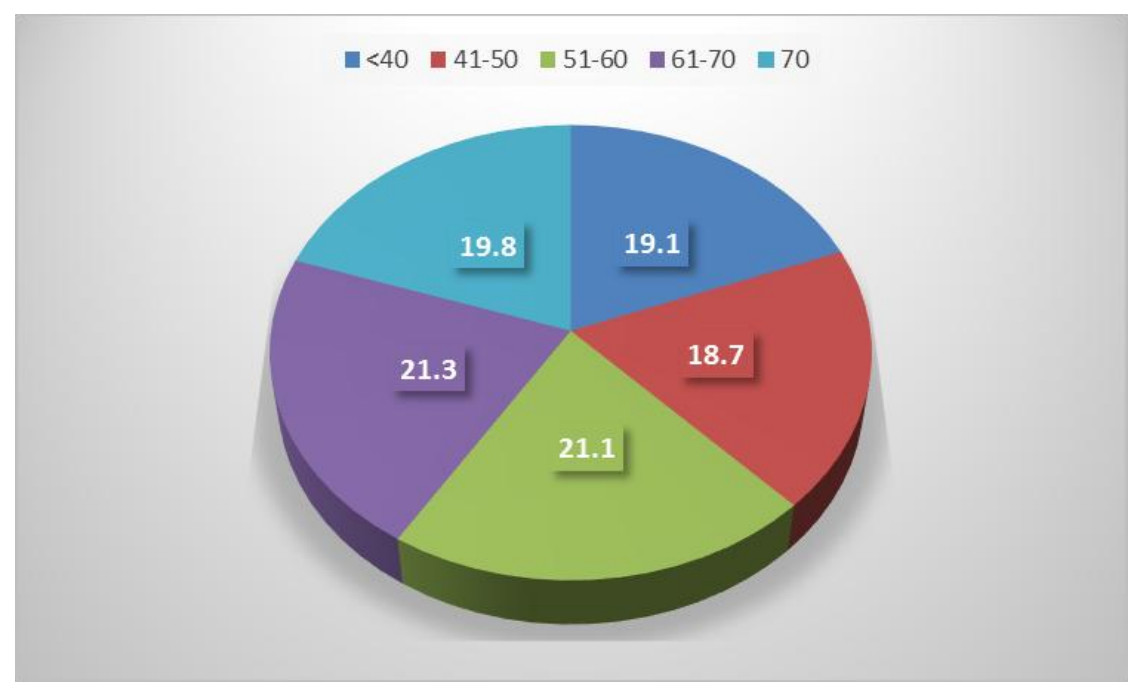

Fig. 1:- Distribution of the studied patients regarding age

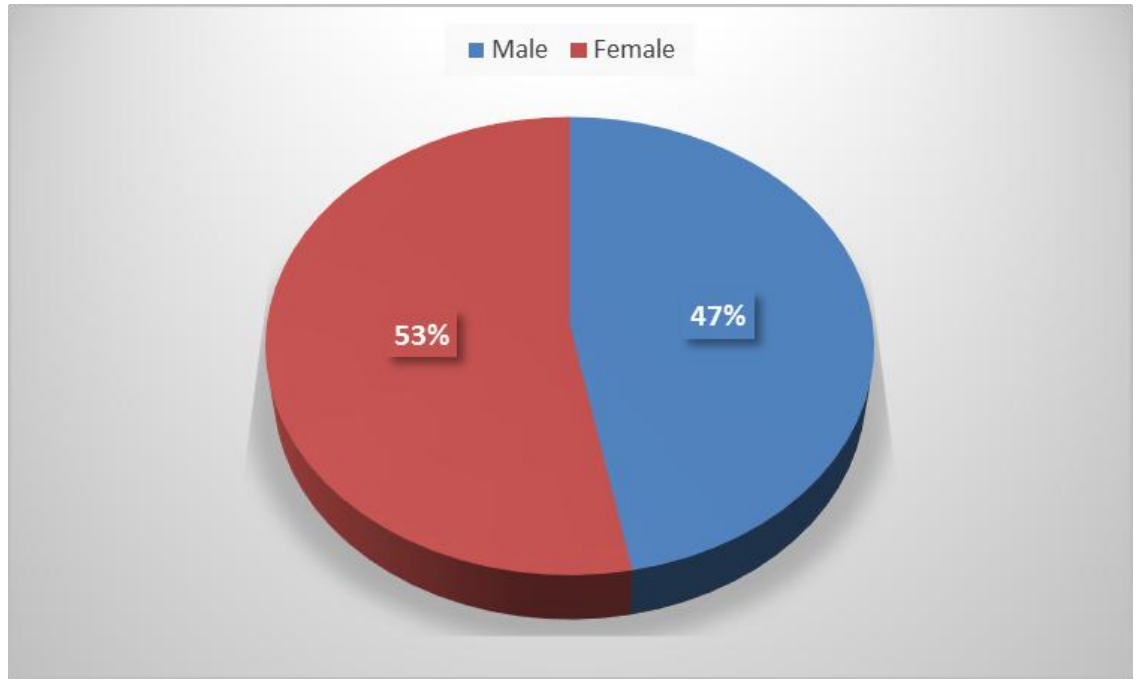

Fig. 2:- Distribution of the studied patients regarding sex

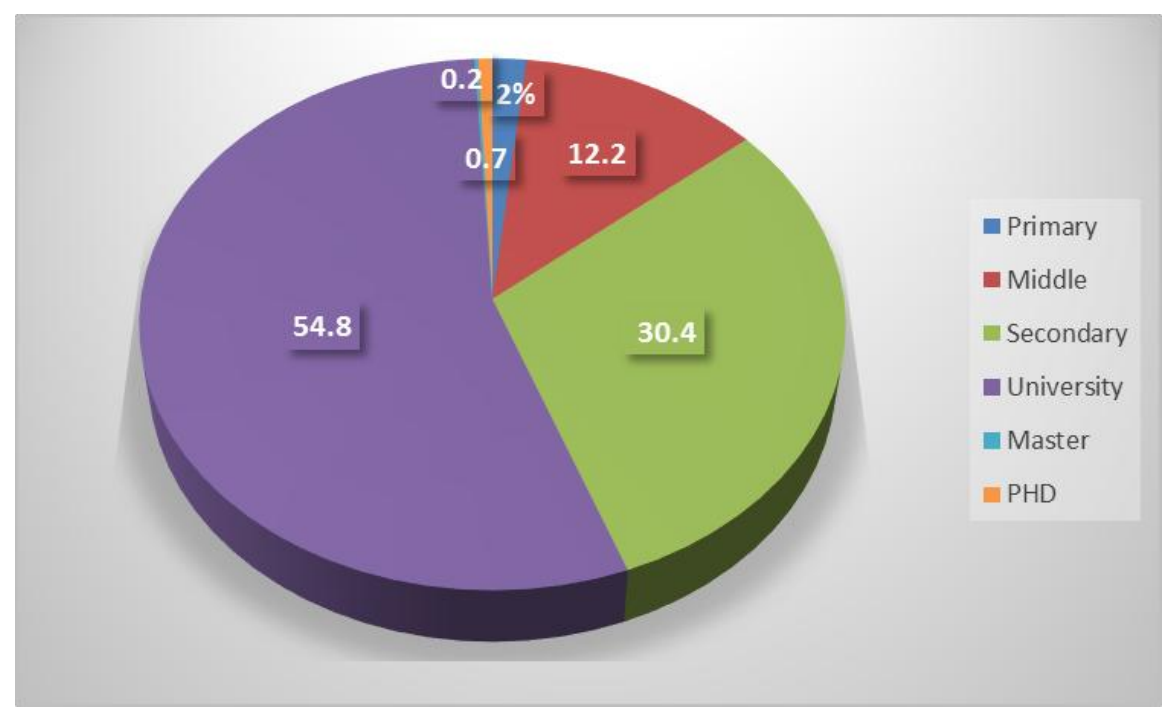

Fig. 3:- Distribution of the studied patients regarding education. 
Incidence of osteoporosis:

Table 2:- Incidence of osteoporosis among the sample and their family history.

\begin{tabular}{|c|c|c|}
\hline & Number & Percent \\
\hline \multicolumn{3}{|c|}{ I am suffering from osteoporosis } \\
\hline No & 306 & 66.5 \\
\hline Yes & 48 & 10.4 \\
\hline Not sure & 106 & 23.0 \\
\hline \multicolumn{3}{|c|}{ There are members of my family who is suffering from osteoporosis: } \\
\hline No & 209 & 45.4 \\
\hline Yes & 133 & 28.9 \\
\hline Not sure & 118 & 25.7 \\
\hline
\end{tabular}

Table (2), show the incidence of osteoporosis among the sample and their family history, from this table it was found that only $10.4 \%$ of the studied group suffering from osteoporosis. While $28.9 \%$ of them had at least one of his family suffering from osteoporosis (Fig. 4-5).

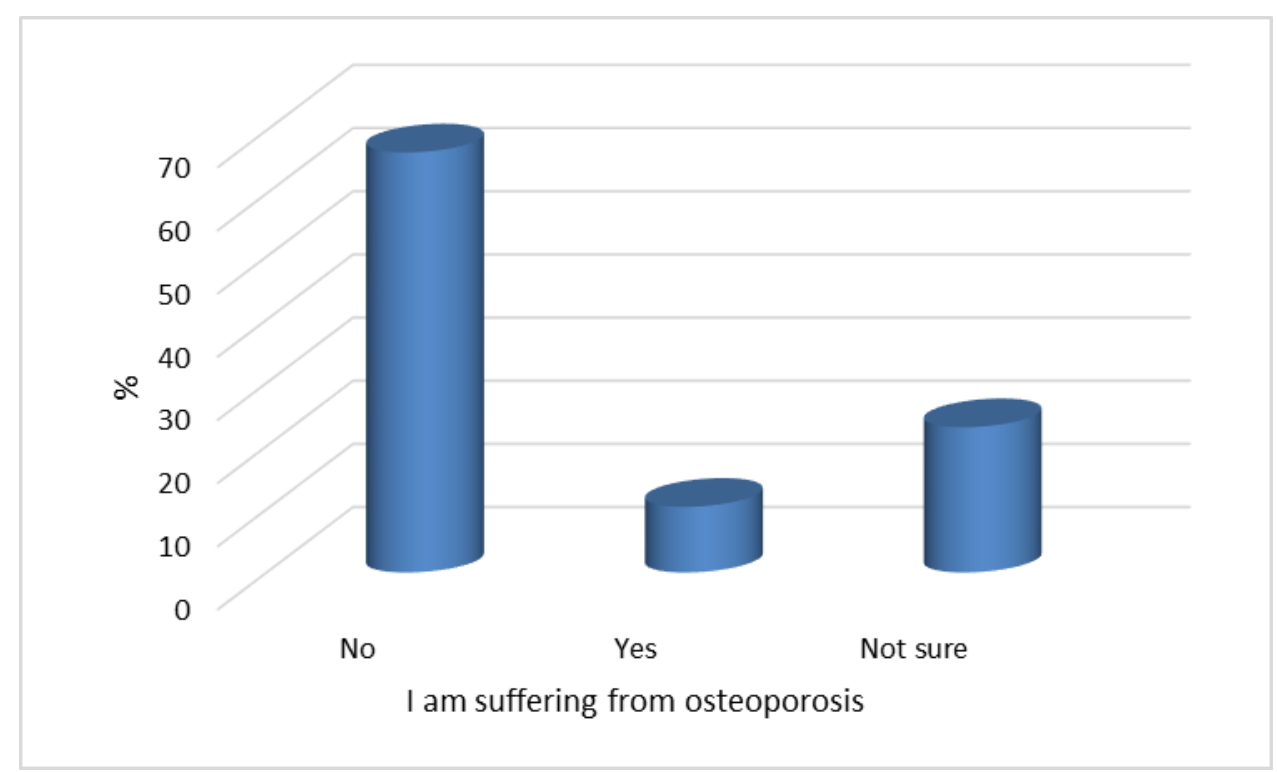

Fig. 4:- Incidence of osteoporosis among the sample.

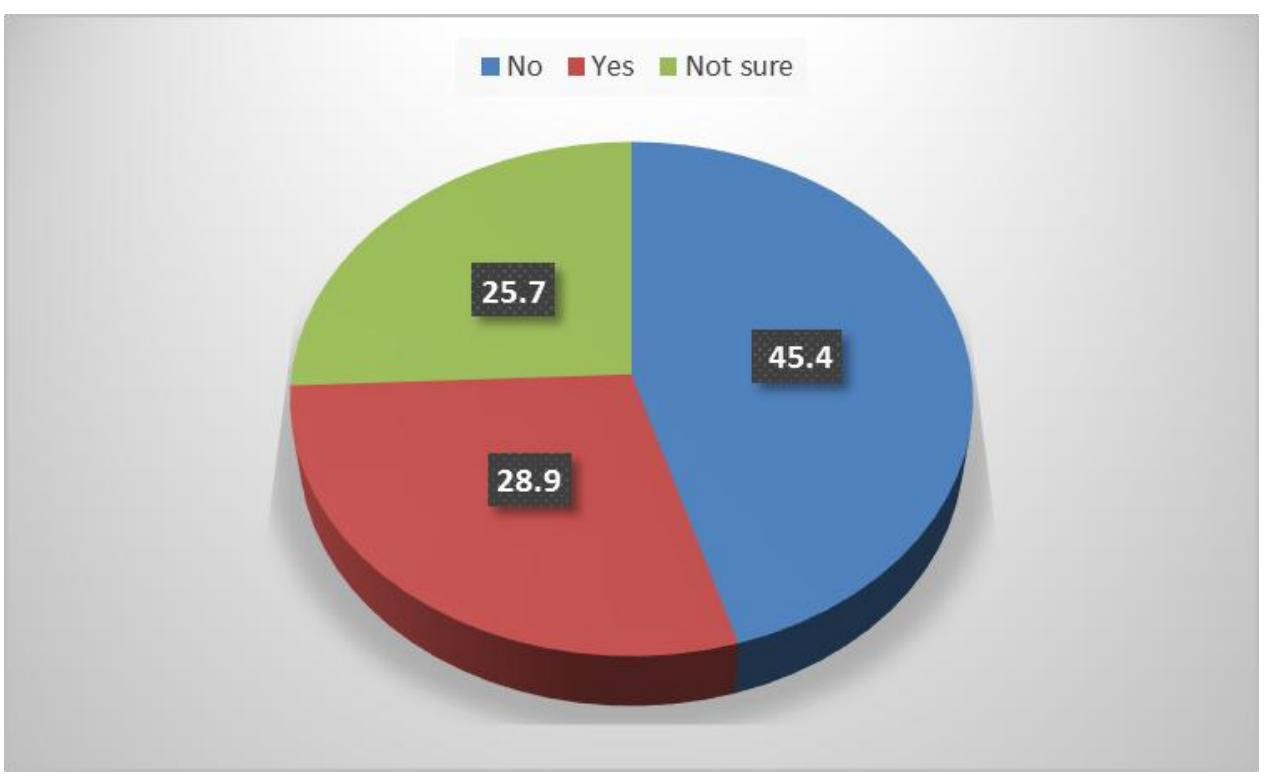

Fig. 5:- Incidence of osteoporosis among their family. 
Knowledge assessment:-

Table 3:- Responses to questions on assessment level of knowledge toward osteoporosis.

\begin{tabular}{|c|c|c|}
\hline & Number & Percent \\
\hline \multicolumn{3}{|l|}{$\begin{array}{l}\text { I understand the concept of } \\
\text { osteoporosis: }\end{array}$} \\
\hline No & 98 & 21.3 \\
\hline Yes & 217 & 47.2 \\
\hline Not sure & 145 & 31.5 \\
\hline \multicolumn{3}{|l|}{$\begin{array}{c}\text { Know the symptoms of } \\
\text { osteoporosis }\end{array}$} \\
\hline No & 129 & 28.0 \\
\hline Yes & 247 & 53.7 \\
\hline Not sure & 84 & 18.3 \\
\hline \multicolumn{3}{|l|}{$\begin{array}{l}\text { I am familiar with the } \\
\text { seriousness of osteoporosis: }\end{array}$} \\
\hline No & 111 & 24.1 \\
\hline Yes & 275 & 59.8 \\
\hline Not sure & 74 & 16.1 \\
\hline \multicolumn{3}{|l|}{$\begin{array}{l}\text { I know that the females has a } \\
\text { high risk to injury osteoporosis }\end{array}$} \\
\hline No & 70 & 15.2 \\
\hline Yes & 316 & 68.7 \\
\hline Not sure & 74 & 16.1 \\
\hline \multicolumn{3}{|l|}{$\begin{array}{l}\text { I know that old age has a high } \\
\text { risk to injury osteoporosis: }\end{array}$} \\
\hline No & 41 & 8.9 \\
\hline Yes & 360 & 78.3 \\
\hline Not sure & 59 & 12.8 \\
\hline \multicolumn{3}{|l|}{$\begin{array}{c}\text { I know that a lack of exposure to } \\
\text { the sun radioactive influential } \\
\text { in a injury disease: }\end{array}$} \\
\hline No & 103 & 22.4 \\
\hline Yes & 268 & 58.3 \\
\hline Not sure & 89 & 19.3 \\
\hline \multicolumn{3}{|l|}{$\begin{array}{l}\text { I know that steroids increase the } \\
\text { risk of injury disease: }\end{array}$} \\
\hline No & 170 & 37.0 \\
\hline Yes & 204 & 44.3 \\
\hline Not sure & 86 & 18.7 \\
\hline
\end{tabular}

Table. 3 showed that the knowledge about osteoporosis is low however higher percentage have good knowledge regarding to the higher risk of osteoporosis among females, old age and lack of exposure to the sun.

Table 4:- Distribution of the studied group regarding their Knowledge score

\begin{tabular}{|l|l|l|l|}
\hline \multicolumn{2}{|l|}{} & Number & Percent \\
\hline & Poor knowledge & 324 & 70.4 \\
\cline { 2 - 4 } & Good Knowledge & 136 & 29.6 \\
\cline { 2 - 4 } & Total & 460 & 100.0 \\
\hline
\end{tabular}


Table (4):- show the distribution of the studied group regarding their Knowledge score, the majority of the subjects had poor knowledge about osteoporosis (Fig. 6).

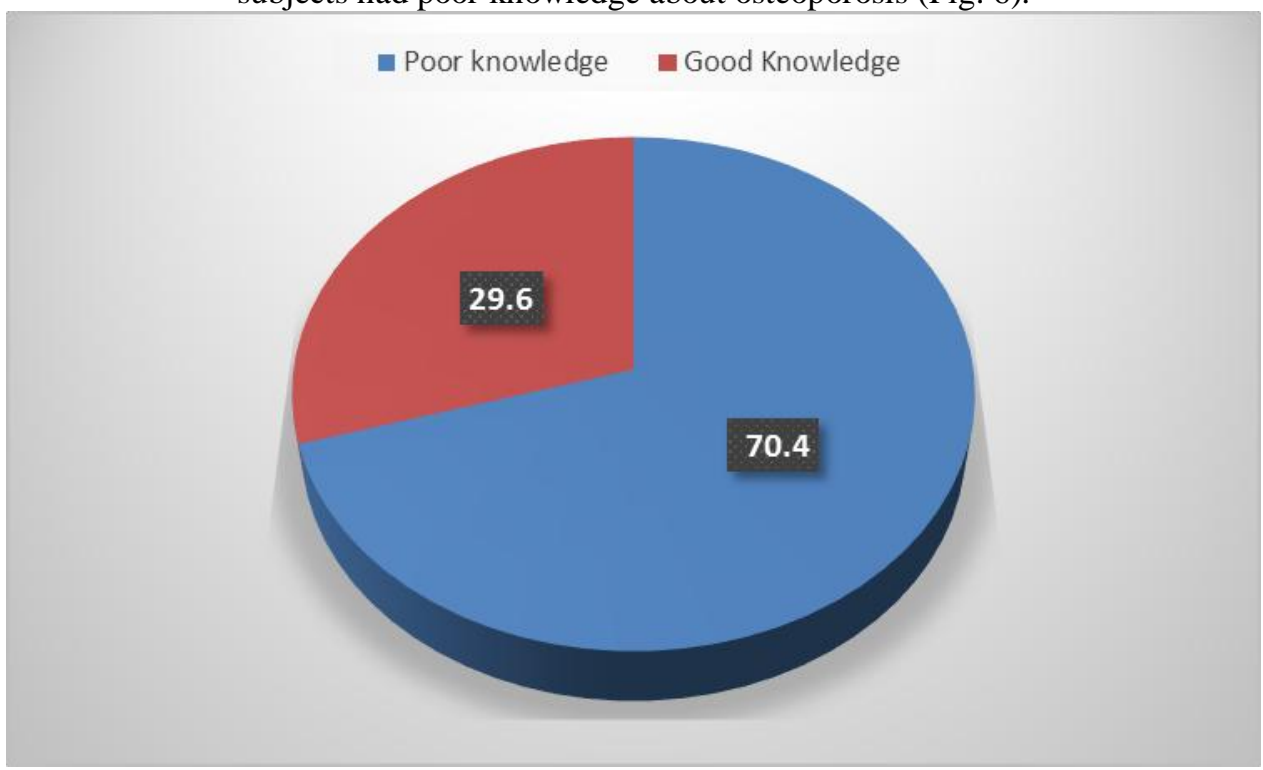

Fig. 6:- Distribution of the studied group regarding their Knowledge score

Level of practice Assessment:-

Table 5:- Responses to questions on assessment level of practice toward osteoporosis.

\begin{tabular}{|c|c|c|}
\hline & Number & Percent \\
\hline \multicolumn{3}{|c|}{$\begin{array}{c}\text { Have you ever attended awareness about the } \\
\text { programs injury osteoporosis }\end{array}$} \\
\hline No & 374 & 81.3 \\
\hline Yes & 86 & 18.7 \\
\hline \multicolumn{3}{|c|}{ Sports practice well: } \\
\hline No & 306 & 66.5 \\
\hline Yes & 154 & 33.5 \\
\hline \multicolumn{3}{|c|}{ Exposed to sun well: } \\
\hline No & 210 & 45.7 \\
\hline Yes & 250 & 54.3 \\
\hline \multicolumn{3}{|c|}{ Be sure to eat foods rich in vitamin D } \\
\hline No & 256 & 55.7 \\
\hline Yes & 204 & 44.3 \\
\hline \multicolumn{3}{|c|}{ Be sure to visit the medical examinations } \\
\hline No & 366 & 79.6 \\
\hline Yes & 94 & 20.4 \\
\hline \multicolumn{3}{|c|}{$\begin{array}{l}\text { Early screening and radiological examination } \\
\text { decrease the risk of osteoporosis and complications. }\end{array}$} \\
\hline No & 96 & 20.9 \\
\hline Yes & 364 & 79.1 \\
\hline
\end{tabular}

Table 5 indicated the practice of participants toward osteoporosis. The majority of participants have never attended awareness programs, practicing sports, eating foods rich in vitamin D as well as visiting the medical examinations. On the other hand, $79.1 \%$ of participants know that early screening and radiological examination decrease the risk of osteoporosis and complications. 
Table 6:- Distribution of the studied group regarding their Practice score.

\begin{tabular}{|l|l|l|l|}
\hline \multicolumn{1}{|l|}{} & Number & Percent \\
\hline & Good practice & 42 & 9.1 \\
\cline { 2 - 4 } & Moderate practice & 186 & 40.4 \\
\cline { 2 - 4 } & Low practice & 232 & 50.4 \\
\cline { 2 - 4 } & Total & 460 & 100.0 \\
\hline
\end{tabular}

Table (6), show the distribution of the studied group regarding their Practice score, only $9.1 \%$ of the sample had a good practice to avoid the disease, while $40.4 \%$ had moderate practice, while the other $50.4 \%$ of the subject had no practice to avoid the disease (Fig. 7).

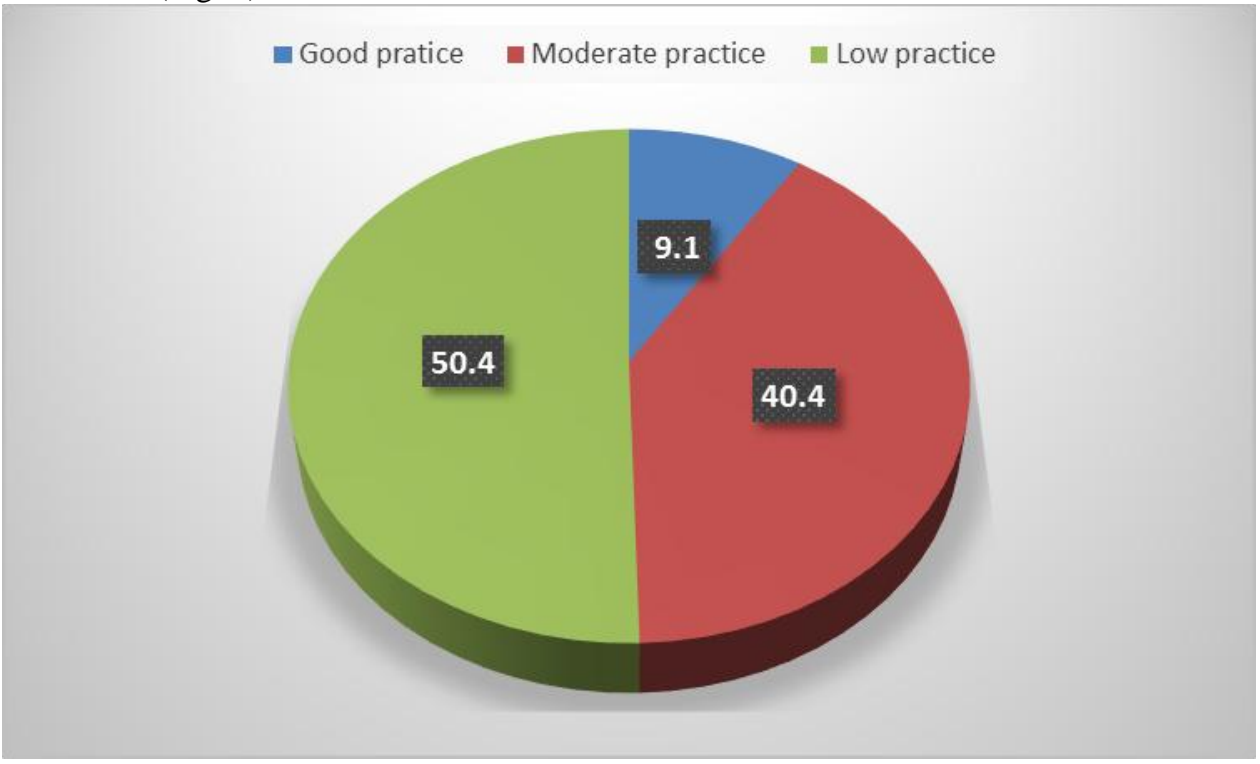

Fig. 7:- Distribution of the studied group regarding their Practice score

Correlation studies between demographic data and participants knowledge:

Table 7:- Relation between level of knowledge and age.

\begin{tabular}{|l|l|l|l|l|l|c|}
\hline \multirow{2}{*}{} & \multicolumn{2}{|l|}{ Knowledge scale } & \multicolumn{2}{l}{ Total } \\
\cline { 2 - 7 } & Good knowledge & \multicolumn{2}{l|}{ Poor knowledge } & \multicolumn{2}{l}{} \\
\cline { 2 - 6 } & No. & \% & No. & \% & No. & \% \\
\hline$<40$ & 56 & 41.2 & 32 & 9.9 & 88 & 19.1 \\
\hline $41-50$ & 42 & 30.9 & 44 & 13.6 & 86 & 18.7 \\
\hline $51-60$ & 32 & 23.5 & 65 & 20.1 & 97 & 21.1 \\
\hline $61-70$ & 3 & 2.2 & 95 & 29.3 & 98 & 21.3 \\
\hline+70 & 3 & 2.2 & 88 & 27.2 & 91 & 19.8 \\
\hline Total & 136 & 324 & & & \\
\hline $\mathrm{X}^{2}$ & 28.15 & & & & \\
$\mathrm{P}$ & $0.001 *$ & & & \\
\hline
\end{tabular}

Table (7), show the relation between level of knowledge and age, it was found that the young age subjects had a good knowledge than the old age subjects $(\mathrm{p}<0.05)$ (Fig. 8). 


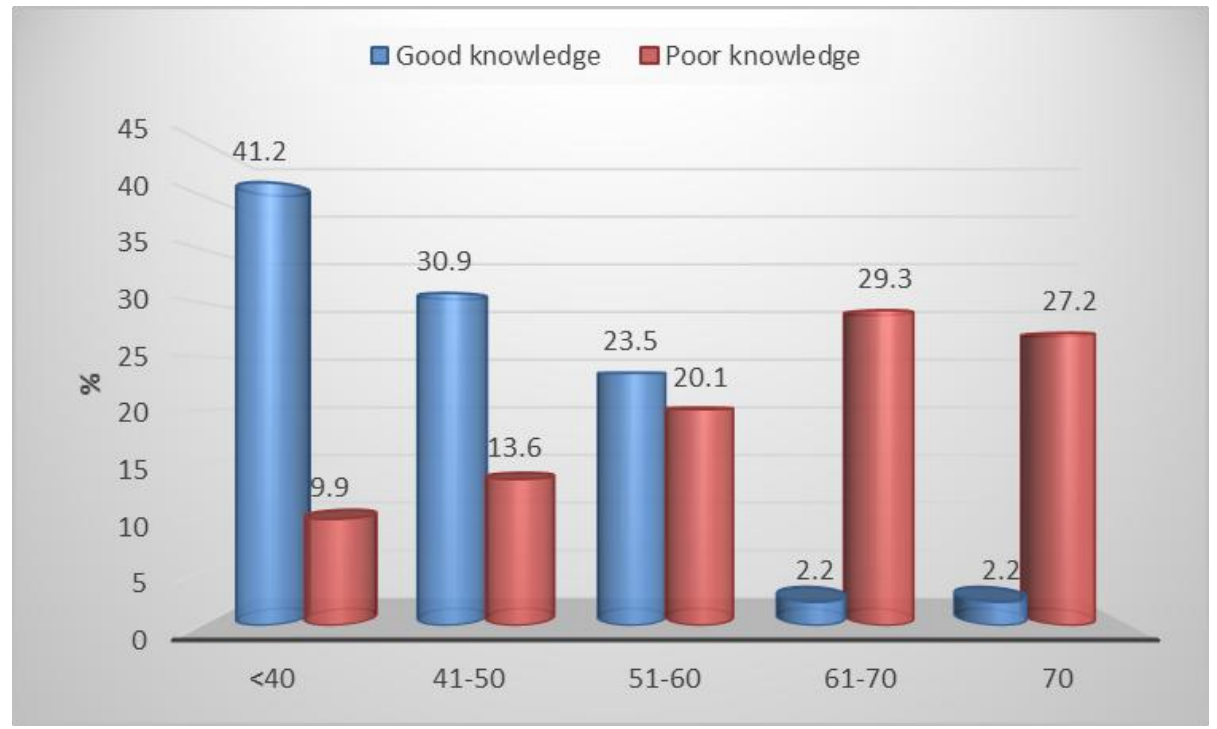

Fig. 8:- Relation between level of knowledge and age.

Table 8:- Relation between level of knowledge and gender.

\begin{tabular}{|l|l|l|l|l|l|l|}
\hline \multirow{2}{*}{} & \multicolumn{2}{|l|}{ Knowledge scale } & \multicolumn{2}{l}{ Total } \\
\cline { 2 - 7 } & Good knowledge & \multicolumn{2}{l|}{ Poor knowledge } & \multicolumn{2}{l|}{} \\
\cline { 2 - 7 } & No. & $\mathbf{\%}$ & No. & \% & No. & \% \\
\hline Male & 65 & 47.8 & 151 & 46.6 & 216 & 47.0 \\
\hline Female & 71 & 52.2 & 173 & 53.4 & 244 & 53.0 \\
\hline Total & 136 & 324 & & & \\
\hline$X^{2}$ & 0.05 & & & & \\
$P$ & 0.815 & & & & & \\
\hline
\end{tabular}

Table (8), show the relation between level of knowledge and gender, it was found that there was no significant effect of gender on the knowledge about osteoporosis ( $p>0.05)$ (Fig. 9).

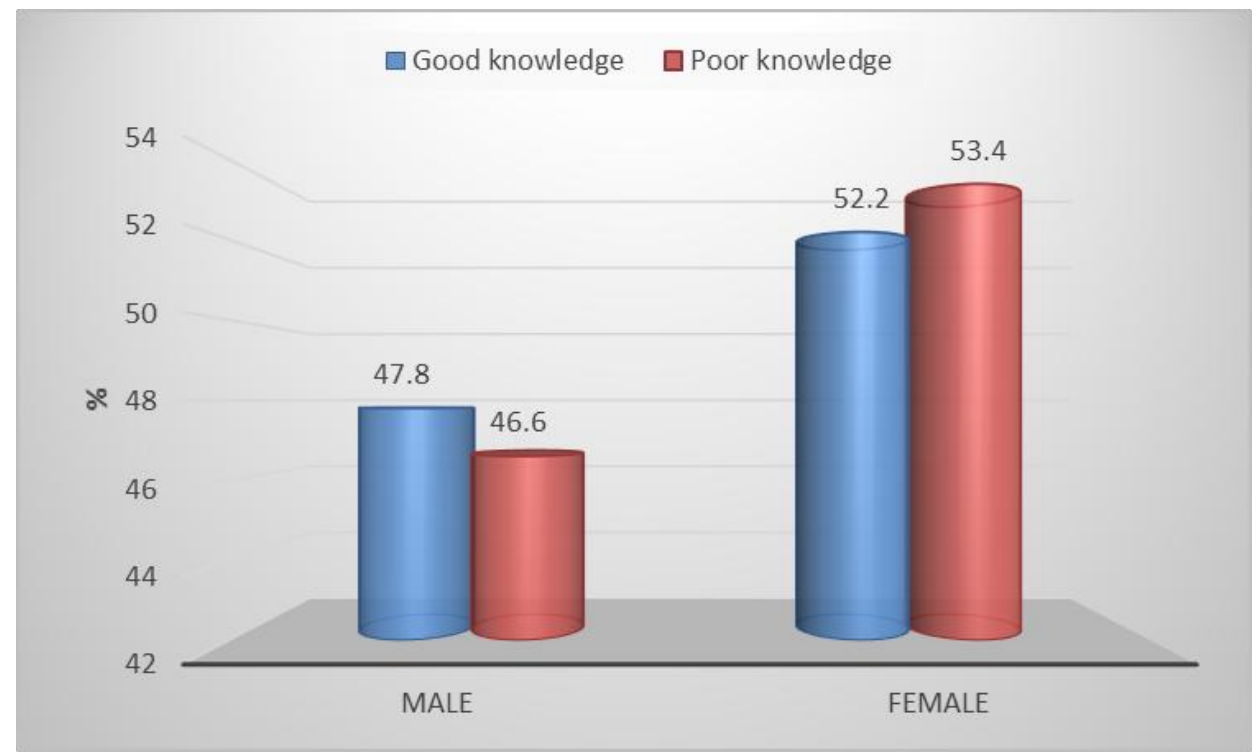

Fig 8:- Relation between level of knowledge and gender. 
Table 9:- Relation between level of knowledge and education

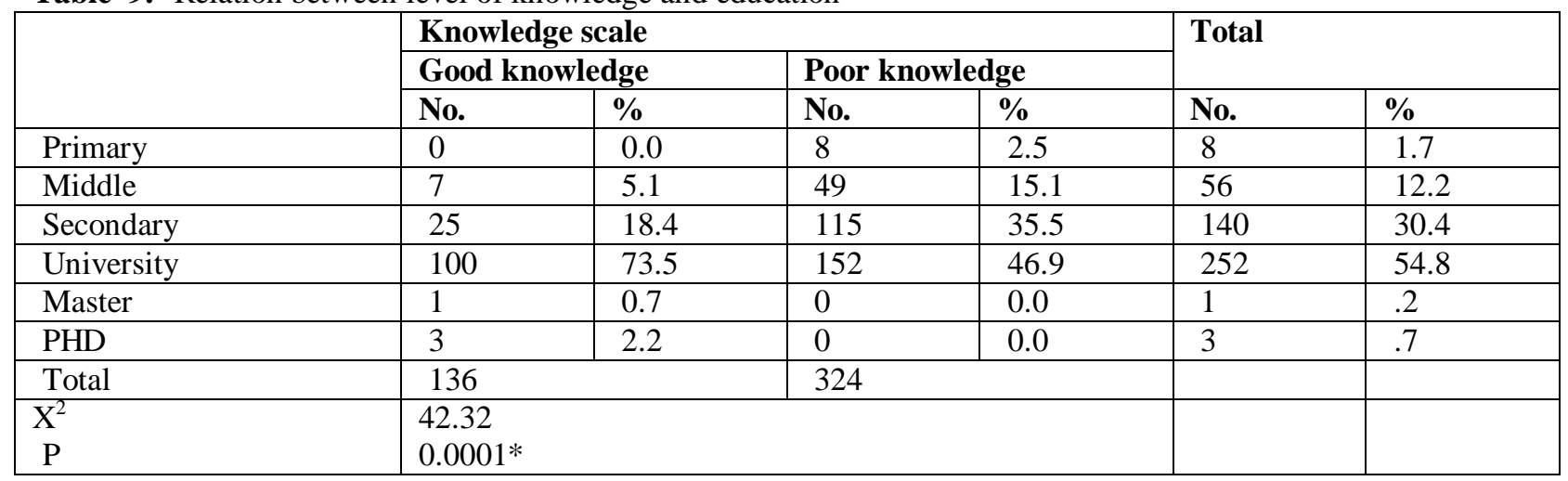

Table (9), show the relation between level of knowledge and education, it was found that there was a significant effect of level of education on the level of knowledge ( $p<0.05)$ (Fig. 10).

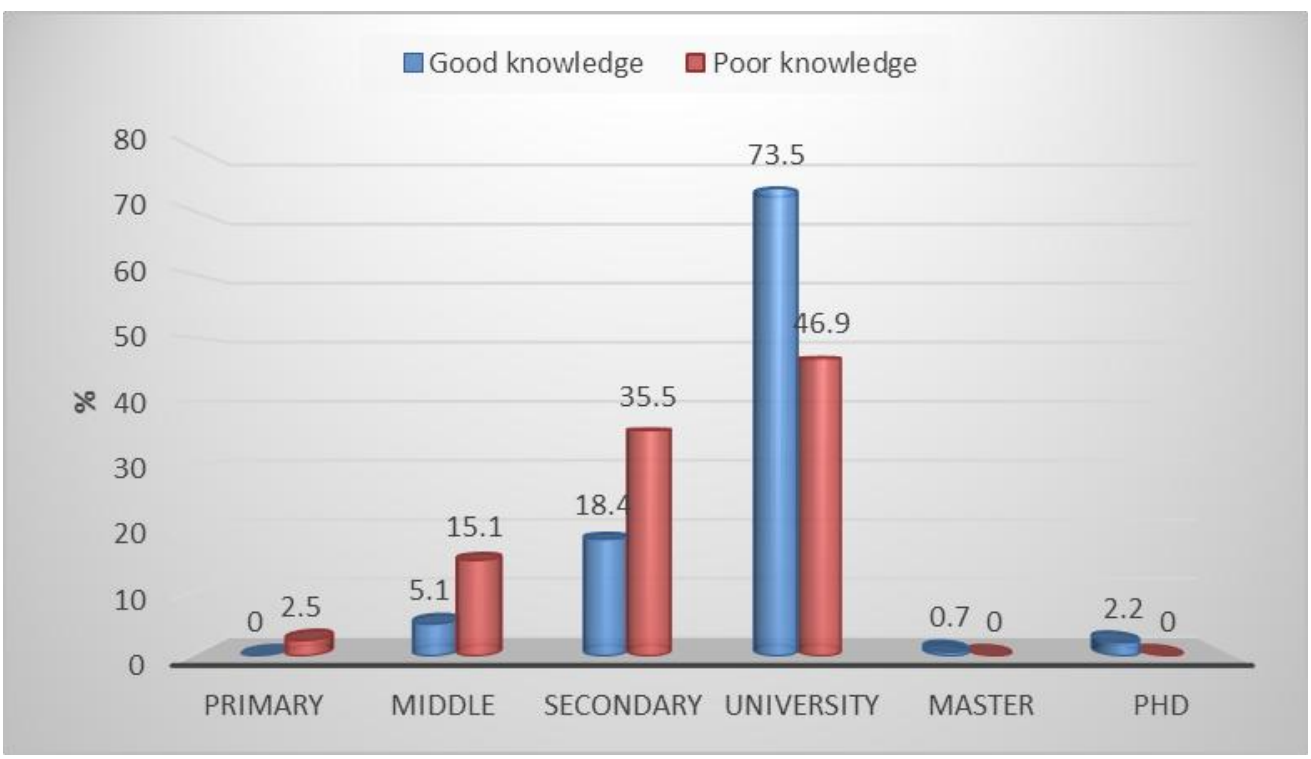

Fig. 10:- Relation between level of knowledge and education

Table 10:- Relation between level of practice and age.

\begin{tabular}{|c|c|c|c|c|c|c|c|c|}
\hline & \multicolumn{6}{|c|}{ Practice } & \multirow{2}{*}{\multicolumn{2}{|c|}{ Total }} \\
\hline & \multicolumn{2}{|c|}{ Good practice } & \multicolumn{2}{|c|}{ Moderate practice } & \multicolumn{2}{|c|}{ Low practice } & & \\
\hline & No. & $\%$ & No. & $\%$ & No. & $\%$ & No. & $\%$ \\
\hline$<40$ & 20 & 47.6 & 39 & 21.0 & 29 & 12.5 & 88 & 19.1 \\
\hline $41-50$ & 18 & 42.9 & 35 & 18.8 & 33 & 14.2 & 86 & 18.7 \\
\hline $51-60$ & 4 & 9.5 & 46 & 24.7 & 47 & 20.3 & 97 & 21.1 \\
\hline $61-70$ & 0 & 0.0 & 60 & 32.3 & 38 & 16.4 & 98 & 21.3 \\
\hline+70 & 0 & 0.0 & 6 & 3.2 & 85 & 36.6 & 91 & 19.8 \\
\hline Total & \multicolumn{2}{|l|}{42} & \multicolumn{2}{|c|}{186} & \multicolumn{2}{|c|}{232} & & \\
\hline $\begin{array}{l}X^{2} \\
P\end{array}$ & \multicolumn{4}{|l|}{$\begin{array}{l}26.85 \\
0.001 *\end{array}$} & & & & \\
\hline
\end{tabular}

Table (10), show the relation between level of knowledge and age, it was found that there was a significant positive effect of the age on good practice to avoid the disease. $(\mathrm{p}<0.01)$. The young age had good practice than the old age subjects (Fig. 11). 


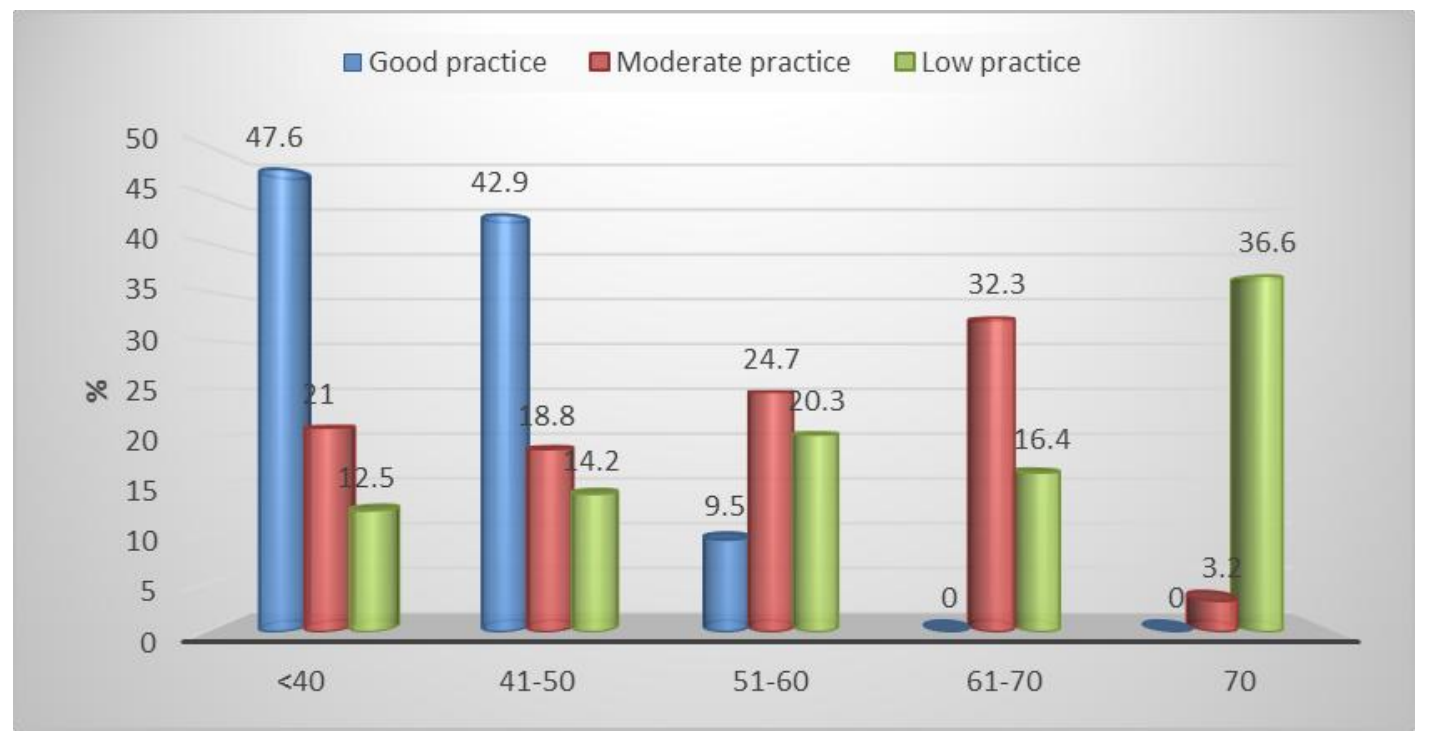

Fig. 11:- Relation between level of practice and age.

Table 11:- Relation between level of practice and gender.

\begin{tabular}{|c|c|c|c|c|c|c|c|c|}
\hline & \multicolumn{6}{|c|}{ Practice } & \multirow{2}{*}{\multicolumn{2}{|c|}{ Total }} \\
\hline & \multicolumn{2}{|c|}{ Good practice } & \multicolumn{2}{|c|}{ Moderate practice } & \multicolumn{2}{|c|}{ Low practice } & & \\
\hline & No. & $\%$ & No. & $\%$ & No. & $\%$ & No. & $\%$ \\
\hline Male & 22 & 52.4 & 42 & 22.6 & 152 & 65.5 & 216 & 47.0 \\
\hline Female & 20 & 47.6 & 144 & 77.4 & 80 & 34.5 & 244 & 53.0 \\
\hline Total & \multicolumn{2}{|c|}{42} & \multicolumn{2}{|l|}{186} & \multicolumn{2}{|l|}{232} & & \\
\hline $\begin{array}{l}X^{2} \\
P \\
\end{array}$ & \multicolumn{4}{|c|}{$\begin{array}{l}26.5 \\
0.0001 *\end{array}$} & & & & \\
\hline
\end{tabular}

Table (11), show the relation between level of knowledge and gender, it was found that there was a significant positive effect of gender on good practice to avoid the disease. $(\mathrm{p}<0.01)$. The male showed low practice than the females (Fig. 12).

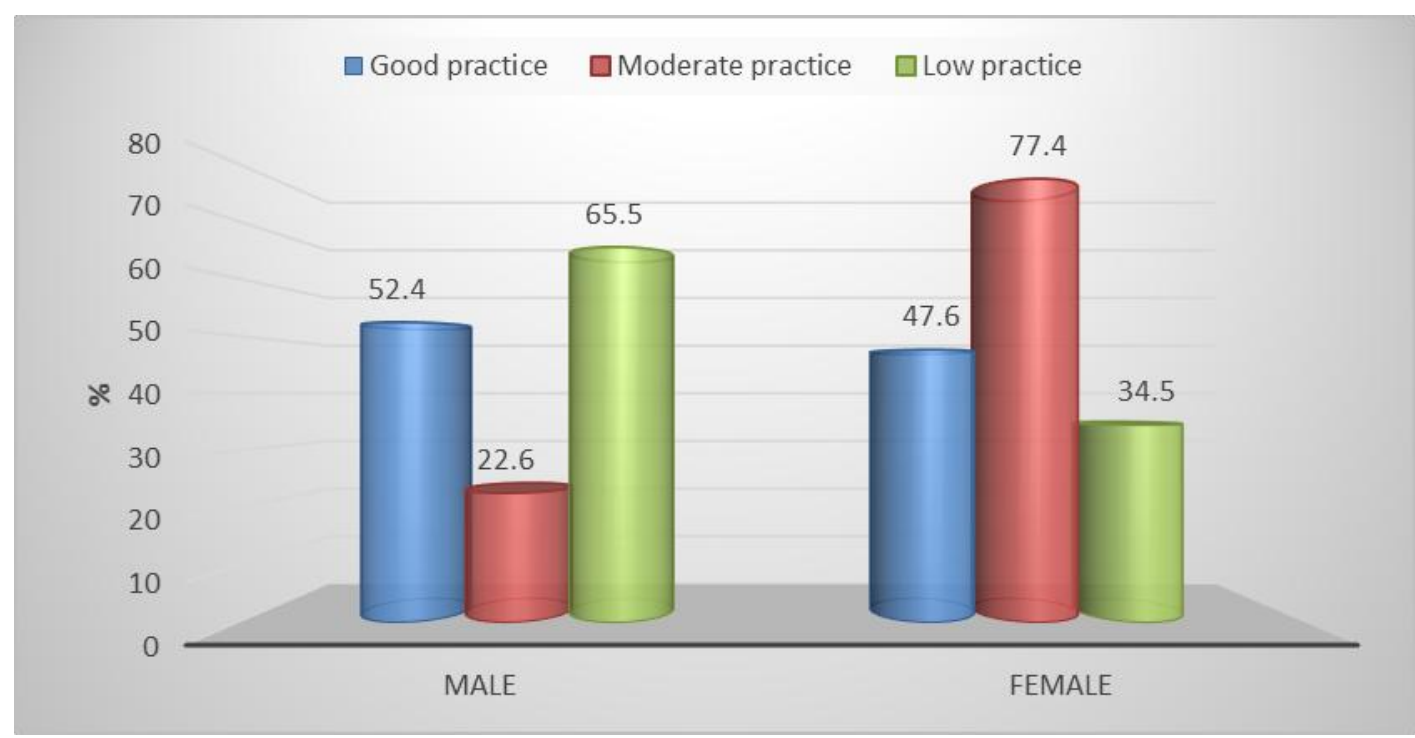

Fig. 12:- Relation between level of practice and gender. 
Table 12:- Relation between level of practice and education

\begin{tabular}{|c|c|c|c|c|c|c|c|c|}
\hline & \multicolumn{6}{|c|}{ Practice } & \multirow{2}{*}{\multicolumn{2}{|c|}{ Total }} \\
\hline & \multicolumn{2}{|c|}{ Good practice } & \multicolumn{2}{|c|}{ Moderate practice } & \multicolumn{2}{|c|}{ Low practice } & & \\
\hline & No. & $\%$ & No. & $\%$ & No. & $\%$ & No. & $\%$ \\
\hline Primary & 0 & 0.0 & 0 & 0.0 & 8 & 3.4 & 8 & 1.7 \\
\hline Middle & 0 & 0.0 & 19 & 10.2 & 37 & 15.9 & 56 & 12.2 \\
\hline Secondary & 22 & 52.4 & 101 & 54.3 & 17 & 7.3 & 140 & 30.4 \\
\hline University & 16 & 38.1 & 66 & 35.5 & 170 & 73.3 & 252 & 54.8 \\
\hline Master & 1 & 2.4 & 0 & 0.0 & 0 & 0.0 & 1 & 0.2 \\
\hline PHD & 3 & 7.1 & 0 & 0.0 & 0 & 0.0 & 3 & 0.7 \\
\hline Total & \multicolumn{2}{|l|}{42} & \multicolumn{2}{|l|}{186} & \multicolumn{2}{|l|}{232} & & \\
\hline $\begin{array}{l}X^{2} \\
P\end{array}$ & \multicolumn{6}{|c|}{$\begin{array}{l}29.85 \\
0.0001 *\end{array}$} & & \\
\hline
\end{tabular}

Table (12), show the relation between level of knowledge and education, it was found that there was a significant positive effect of level of education on good practice to avoid the disease. $(\mathrm{p}<0.01)$. I.e. The high educated had a good practice (Fig. 13).

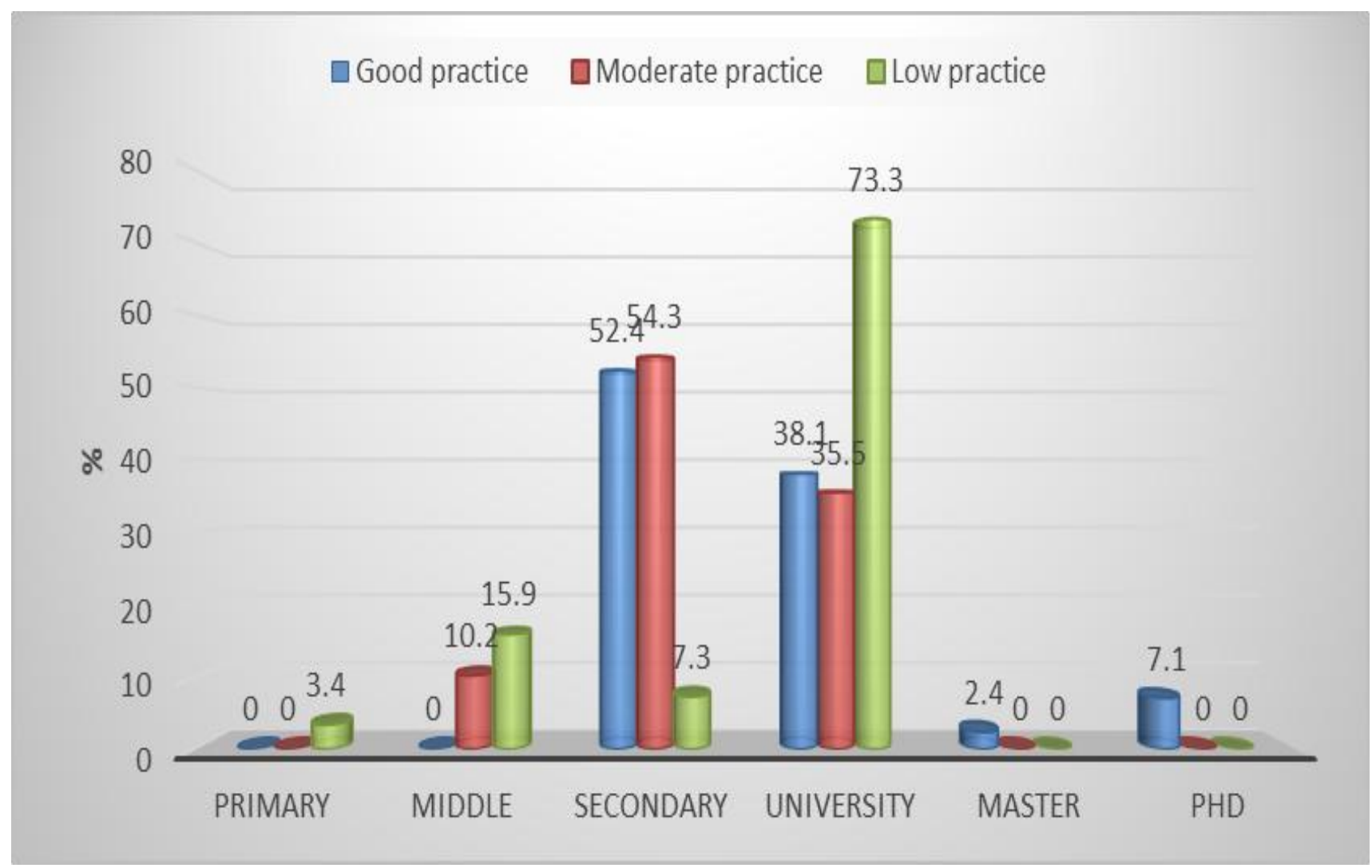

Fig. 13:- Relation between level of practice and education

\section{Discussion:-}

Osteoporosis has been recognized as a major public health problem by healthcare providers in Saudi Arabia. Sufficient information about knowledge, health beliefs, and some of the life habits are important toplan for the disease prevention. The present study examined the osteoporosis knowledge, andsome of the life habits of Saudi participants in Jeddah to examine health beliefs about osteoporosis and osteoporosis radiological screening in a large group of older women and men to determine barriers to screening. 
In this study, the majority of the subjects had poor knowledge about osteoporosis and $50.4 \%$ of the subject had no practice to avoid the disease. In partial accordance with these results, a recent study in Saudi Arabia showed that themajority of women in this study had a modest knowledge on osteoporosis. Regarding to practices towards preventing osteoporosis, it was inadequate in studied groups ${ }^{(21)}$.

However, another study among adults in Riyadh showed that participants' knowledge score was about $57 \%$ of the total score and practice score was $51.7 \%{ }^{(22)}$. These scores are higher than our results and this could be attributed to different age and population size between the two studies.

The level of education showed a significant correlation with knowledge of osteoporosis. Also, the young age, higher level of education and females had significantly higher correlation with good practice. In agreement, there were significant associations between the level of awareness, practice and the sociodemographics of the participants including age, female gender and education ${ }^{(23)}$.

In conclusion, this study indicated a lack of awareness and practice about osteoporosis. There was a significant association between knowledge and practice with level of education. Also, the female gender and age showed higher practice scores.All these resultsshowed the significance of more health staff involvement regarding to awareness campaign about osteoporosis.

\section{References:-}

1. Drake MT, Clarke BL, Lewiecki EM.The Pathophysiology and Treatment of Osteoporosis. Clinical therapeutics. 2015;37(8):1837-50.

2. Sadat-Ali M, Al-Habdan IM, Al-Turki HA, Azam MQ.An epidemiological analysis of the incidence of osteoporosis and osteoporosis-related fractures among the Saudi Arabian population. Ann Saudi Med. 2012;32(6):637-41.

3. Alquaiz AM, Kazi A, Tayel S, Shaikh SA, Al-Sharif A, Othman S, et al.Prevalence and factors associated with low bone mineral density in Saudi women: a community based survey. BMC musculoskeletal disorders. 2014;15:5.

4. IOF.The International Osteoporosis Foundation (IOF). Http://www.iofbonehealth.org/facts-statistics\#category28.

5. Al-Zu'bi A, Almuhtaseb N, Amayreh I.Osteoporosis awareness in a sample of teenage girls in Jordan. Jordan Medical Journal. 2010;44(4):420-26.

6. Gehlbach SH, Fournier M, Bigelow C.Recognition of osteoporosis by primary care physicians. Am J Public Health. 2002;92(2):271-3.

7. Morris CA, Cabral D, Cheng H, Katz JN, Finkelstein JS, Avorn J, et al.Patterns of bone mineral density testing: current guidelines, testing rates, and interventions. J Gen Intern Med. 2004;19(7):783-90.

8. Codori AM, Petersen GM, Miglioretti DL, Boyd P.Health beliefs and endoscopic screening for colorectal cancer: potential for cancer prevention. Preventive medicine. 2001;33(2 Pt 1):128-36.

9. Weinberg DS, Turner BJ, Wang H, Myers RE, Miller S.A survey of women regarding factors affecting colorectal cancer screening compliance. Preventive medicine. 2004;38(6):669-75.

10. Wallace LS.Osteoporosis prevention in college women: application of the expanded health belief model. American journal of health behavior. 2002;26(3):163-72.

11. Sedlak CA, Doheny MO, Jones SL.Osteoporosis education programs: changing knowledge and behaviors. Public Health Nurs. 2000;17(5):398-402.

12. Bandura A.Health promotion by social cognitive means. Health education \& behavior : the official publication of the Society for Public Health Education. 2004;31(2):143-64.

13. Rosenstock IM, Strecher VJ, Becker MH.Social learning theory and the Health Belief Model. Health education quarterly. 1988;15(2):175-83.

14. Gourlay M, Richy F, Reginster JY.Strategies for the prevention of hip fracture. The American journal of medicine. 2003;115(4):309-17.

15. Gallagher TC, Geling O, Comite F.Missed opportunities for prevention of osteoporotic fracture. Archives of internal medicine. 2002;162(4):450-6.

16. Nelson HD, Helfand M, Woolf SH, Allan JD.Screening for postmenopausal osteoporosis: a review of the evidence for the US Preventive Services Task Force. Annals of internal medicine. 2002;137(6):529-41. 
17. O'Sullivan J, O'Connor OJ, O'Regan K, Clarke B, Burgoyne LN, Ryan MF, et al.An assessment of medical students' awareness of radiation exposures associated with diagnostic imaging investigations. Insights Imaging. 2010;1(2):86-92.

18. Sani KG, Jafari M, Mohammadi M, Mojiri M, Rahimi A.Iranian physicians' knowledge about radiation dose, received by patients in diagnostic radiology. Iranian Journal of Radiation Research. 2009;6:207-12.

19. Http://www.calculator.net/sample-sizecalculator. html? Type $=1 \& \mathrm{cl}=95 \& \mathrm{ci}=5 \& \mathrm{ps}=3 \% 2 \mathrm{C} 976 \% 2 \mathrm{C} 000 \& \mathrm{x}=37 \& \mathrm{y}=6$.

20. 50 SY.Central Department Of Statistics \& Information. 2014.

21. Al-Otaibi HH.Osteoporosis Health Beliefs, Knowledge and Life Habits among Women in Saudi Arabia. Open Journal of Preventive Medicine. 2015;5(06):236.

22. Barzanji AT, Alamri FA, Mohamed AG.Osteoporosis: a study of knowledge, attitude and practice among adults in Riyadh, Saudi Arabia. Journal of community health. 2013;38(6):1098-105.

23. Alamri FA, Saeedi MY, Mohamed A, Barzanii A, Aldayel M, Ibrahim AK.Knowledge, attitude, and practice of osteoporosis among Saudis: a community-based study. J Egypt Public Health Assoc. 2015;90(4):171-7. 